\title{
Phytochemical profile of some green leafy vegetables in South East, Nigeria
}

\author{
Onyeka E. U. * and Nwambekwe, I.O \\ Department of Food Science and Technology, \\ Federal University of Technology, Owerri, Nigeria \\ *Address for correspondence:- E-mail: ulomaonyeka@yahoo.com
}

ABSTRACT

\begin{abstract}
The potential of eight common green leafy vegetables (GLV) in the raw and cooked forms as natural source of phytochemicals was assessed. The vegetables studied were the common ones found in southeast Nigeria and they included Ugu, Nchanwu, Okazi, Utazi, Oha, Nturukpa, Ahihara, and Onugbo. The vegetables were assessed for the following phytochemicals: alkaloid, steroid, tannin, anthocyanin, carotenoids and flavonoid. The phytochemical content of the vegetables varied significantly $(\mathrm{p}=0.05)$ among the GLV. Onugbo had the highest steroid content of $0.27 \mathrm{~g} / 100 \mathrm{~g}$ while nchanwu had the lowest $(0.07 \mathrm{~g} / 100 \mathrm{~g})$. Oha followed by ahihara was the most enriched with respect to the tested
\end{abstract}

\section{INTRODUCTION}

$\mathrm{P}$ hytochemical simply means plant chemicals. They are naturally occurring components in fruits, vegetables, legumes and grains. They give plants its colour, flavour, smell and are part of a plant's natural defense system (disease resistance). According to Liu (2004), phytochemicals are bioactive, non-nutrient plant compounds in fruits, vegetables, grains and other plant foods that have been linked to reducing the risk of major degenerative diseases. In his report, Anderson, (2004) defined phytochemicals as plant-derived chemicals, which are beneficial to human health and disease prevention. In plants phytochemicals attract beneficial and repel harmful organisms, serve as photoprotectants, phytochemicals. Differences in phytochemical content between raw and cooked GLV were not significant $(\mathrm{p}=0.05)$, with the exception of flavonoid and alkaloids. Generally the GLV showed a low content of anthocyanin and carotenoids while alkaloid was most abundant in them. Alkaloid content of the GLV in raw and cooked forms were $1.28-2.96 \mathrm{~g} / 100 \mathrm{~g}$ and $0.30-0.84 \mathrm{~g} / 100 \mathrm{~g}$ respectively. The assessed GLV offer a cheap but rich source of a number of phytochemicals having health protective properties. The production and consumption of a mixture of GLV is recommended.

Key words: Phytochemical, green leafy vegetables, cooking, nutrient, antioxidant 
nutrients have potentials in helping to reduce the risk of several deadly diseases in man (Williamson et al., 1997; Stahl et al., 1998; Agte et al., 2000; Chung et al., 1998). Reports show that these phytochemicals reduce LDL i.e. the cholesterol involved in depositing fat in the arteries (Anderson, 2004), prevent blood clotting which can reduce the risk for a heart attack or a stroke. Sulphur compounds, which are examples of phytochemicals, are known also to reduce the cholesterol production in the body and through that keep the blood pressure down (Anderson, 2004; Akpanyung, et al, 1995. They do this either by working alone or in the combination of vitamins and other nutrients in foods (Liu, 2004).

Reports show that the greatest sources of these phytochemicals are fruits and vegetables (Willet, 2002; Liu, 2004, Altar and Adeogun, 1995). Hence we need to discover the potentials of our local vegetables in possessing these phytonutrients. This will help to provide vital data for food processors and nutrition workers as well as the consumers for selection of these GLV. There are over 3000 discovered phytochemicals in plants (Oliveri, 2003). However the levels of these plant chemicals may vary depending on specie and varieties of GLV. Furthermore these chemicals may be affected by food processing, limiting the use of raw values for estimating the phytochemical profile. Thus, the objective of this research is to determine the content of phytochemicals in the selected GLV commonly consumed in SouthEast Nigeria and to assess the effect of cooking on these phytochemicals.

\section{MATERIALS AND METHODS Collection of materials}

The tested vegetables were procured from a local market and identified at National Root Crops Research Institute, Umuahia Nigeria. The GLV used in this study with their botanical names are shown in Table 1.

Table 1 Botanical names of reported green leafy vegetables

\begin{tabular}{ll}
\hline $\begin{array}{l}\text { Common name } \\
\text { Igbo/English }\end{array}$ & Botanical name \\
\hline 'Utazi' & Gongronema latifolium \\
'Nchanwu /Scent leaf & Occinum gratissmum \\
'Onugbo' /Bitter leaf & Vernonia amygdalina \\
'Ugu' / Pumpkin & Telferia occidentalis \\
'Ahihara'/Bush Mallow & Corchorus olitorius \\
'Oha' & Pterocarpus mildbreadii \\
'Nturukpa' & Pterocarpus santalinoides \\
'Okazi' & Gnetum africana \\
\hline
\end{tabular}

\section{Sample preparation}

Each GLV was spread out on a laboratory bench and inspected for the presence of variegated, dried and extraneous materials such as dirt and insect larva. After removing the unwanted ones the samples were divided into two parts. One part was used raw and the other part cooked. For the raw samples the leaves were manually plucked from stems and sliced, which were later, comminuted to a uniform pulp in a laboratory mortar. The second part of each sample was 
boiled without any ingredient for $5 \mathrm{~min}$ and drain dry. Adequate portions of each sample (raw and cooked) were weighed out and used for the different analysis.

\section{Qualitative analysis of phytochemicals}

Qualitative analysis were carried out to ascertain the presence of the different phytochemicals in the leaves before quantitative analysis were carried out. The methods used and their corresponding inferences are shown in Table2.

\section{Quantitative analysis of phytochemicals Determination of Alkaloids}

This was done by the alkaline precipitation gravimetric method described by Harborne, (1973). A measured weight of the sample was dispersed in $10 \%$ acetic acid solution in ethanol to form a ratio of 1:10 (10\%). The mixture was allowed to stand for $4 \mathrm{~h}$ at $28^{\circ} \mathrm{C}$. It was later filtered via what man No 42 grade of filter paper. The filtrate was concentrated to one quarter of its original volume by evaporation and treated

Table 2 Qualitative test for phytochemicals

\begin{tabular}{llll}
\hline Phytochemical & \multicolumn{1}{c}{ Test } & \multicolumn{1}{c}{ Observation } & Inference \\
\hline Alkaloid & $\begin{array}{l}\text { Wagner } \\
\text { dragendroff's } \\
\text { Ferric chloride } \\
\text { test }\end{array}$ & $\begin{array}{l}\text { Brown precipitate which turns } \\
\text { intense yellow with picric acid } \\
\text { Greenish-black precipitate }\end{array}$ & Alkaloid present \\
Flavonoid & $\begin{array}{l}\text { Ammonium test } \\
\text { Sodium hydroxide } \\
\text { acid test }\end{array}$ & $\begin{array}{l}\text { Yellow colour } \\
\text { Yellow colour which turned } \\
\text { colourless on addition of acid }\end{array}$ & Flavonoid present \\
& $\begin{array}{l}\text { Liberman Burchard } \\
\text { test }\end{array}$ & Brownish colour & Slavent \\
Steroids & Salkowkeis test & Red colour at interface & Steroid present \\
\hline
\end{tabular}

Methods as described by Harborne (1973)

with drop wise addition of conc. aqueous $\mathrm{NH}_{4} \mathrm{OH}$ until the alkaloid was precipitated. The alkaloid precipitated was received in a weighed filter paper, washed with $1 \%$ ammonia solution dried in the oven at $80^{\circ} \mathrm{C}$. Alkaloid content was calculated and expressed as a percentage of the weight of sample analyzed.

\section{Determination of Flavonoids}

This was determined according to the method of Harborne (1973). 5 gram of the sample was boiled in $50 \mathrm{ml}$ of $2 \mathrm{M} \mathrm{HCl}$ solution for $30 \mathrm{~min}$ under reflux. It was allowed to cool and then filtered through whatman No 42 filter paper. A measured volume of the extract was treated with equal volume of ethyl acetate starting with drop. 
The flavonoid precipitated was recovered by filtration using weighed filter paper. The resulting weight difference gave the weight of flavonoid in the sample.

\section{Determination of Tannin}

Tannin content was determined by the FolisDenis colorimetric method described by Kirk and Sawyer (1998). 5g sample was dispersed in 50mls of distilled water and shaken. The mixture was allowed to stand for $30 \mathrm{~min}$ at $28^{\circ} \mathrm{C}$ before it was filtered through what man No. 42 grade of filter paper. $2 \mathrm{mls}$ of the extract was dispersed into a $50 \mathrm{ml}$ volumetric flask. Similarly $2 \mathrm{ml}$ standard tannin solution (tannic acid) and $2 \mathrm{ml}$ of distilled water were put in separate volumetric flasks to serve as standard and reagent was added to each of the flask and the $2.5 \mathrm{ml}$ of saturated $\mathrm{Na}_{2} \mathrm{C}^{3}$ solution added. The content of each flask was made up to $50 \mathrm{mls}$ with distilled water and allowed to incubate at $28^{\circ} \mathrm{C}$ for $90 \mathrm{~min}$. Their respective absorbance was measured in a spectrophotometer at $260 \mathrm{~nm}$ using the reagent blank to calibrate the instrument at zero.

\section{Determination of Carotenoids}

A measured weight of each sample was homogenized in methanol using a laboratory blender. A 1:10 (1\%) mixture was used. The homogenate was filtered to obtain the initial crude extract. $20 \mathrm{ml}$ of ether were added to the filtrate to take up the carotenoid mixed well and then treated with $20 \mathrm{ml}$ of distilled water in a separating funnel. The other layer was recovered and evaporated to dryness at low temperature (35$50^{\circ} \mathrm{C}$ ) in a vacuum dessicator. The dry extract was then saponified with $20 \mathrm{ml}$ of ethanoic potassium hydroxide and left over night in a dark cupboard. The next day, the carotenoid were taken up in $20 \mathrm{ml}$ of ether and then washed with two portions of $20 \mathrm{ml}$-distilled water. The carotenoid extract (ether layer) was dried in a dessicator and then treated with a light petroleum (petroleum spurt) and allowed to stand overnight in a freezer $\left(-10^{\circ} \mathrm{C}\right)$. The next day, the precipitated steroid was removed by centrifugation and the carotenoid extract was evaporated to dryness in a weighed evaporation dish, cooled in a dessicator and weighed. The weight of carotenoid was determined and expressed as a percentage of the sample weight.

\section{Determination of Steroids}

This was determined by the method described by Okeke and Elekwa (2003). A measured weight of each sample was dispersed in $100 \mathrm{ml}$ freshly distilled water and homogenized in a laboratory blender. The homogenate were filtered and the filtrate was eluted with normal ammonium hydroxide solution ( $\mathrm{pH} 9$ ). $2 \mathrm{ml}$ of the eluate were put in test tube and mixed with $2 \mathrm{ml}$ of chloroform. $3 \mathrm{ml}$ of ice-cold acetic anhydride were added to the mixture in the flask and 2 drops of conc. $\mathrm{H}_{2} \mathrm{SO}_{4}$ were cautiously added to cool. Standard sterol solution was prepared and treated as described above. The absorbance of standard and prepared sample were measured in a spectrophotometer at $420 \mathrm{~nm}$.

\section{Determination of Anthocyanins}

This was done gravimetrically by the method of Harborne (1973). 5g of each test sample was hydrolyzed by boiling in $100 \mathrm{ml}$ or $2 \mathrm{Mhcl}$ solution for $30 \mathrm{~min}$. The hydrolysate was filtered using whatman No 42 filter paper. The filtrate was transferred into a separation funnel and equal volume of ethyl acetate was added to it, mixed well and allowed to separate into two layers. The ethyl acetate layer (extract) was recorded while the aqueous layer was discarded. The extract was separated to dryness in the crucible over a steam bath. The dried extract was then treated with concentrated amyl alcohol to extract the anthocyanins. After filteration, the alcohol extract and the filterate was transferred to a weighed evaporating dish and evaporated to dryness. It was then dried in the oven at $30^{\circ} \mathrm{C}$ 
for 30min and cooled in a desiccator. The weight of anthocynanin was determined and expressed as percentage of the original sample.

\section{Statistical Analysis}

The results obtained were computed into means and ANOVA was used to separate the means according to the method of Ihekoronye and Ngoddy, (1985). The least significant difference (LSD) was used to determine level of differences among the varying samples.

\section{RESULTS AND DISCUSSION}

Generally there was low content of anthocyanin in the green leafy vegetables (Fig 1). Oha leaf, which had the highest anthocyanin content, had a value of $0.1 / 100 \mathrm{~g}$. Ugu and olugbo had the lowest anthocyanin content of $0.02 \mathrm{~g} / 100 \mathrm{~g}$ each. Low content of anthocyanin among the vegetables was expected since anthocyanin is associated with non-green coloured fruits and vegetables (Alais and Linden, 1987; Dewanto et al, 2002). Boiling reduced the anthocyanin content of most of the GLV though the reduction was not significant (Table 3) at $p=0.05$. The reduction in anthocyanin content following heat treatment could be because of release of glucosides that might have converted the natural conjugated bond form of anthocyanin to their corresponding aglycones (Alais and Linden, 1987). Onugbo had the highest steroid content of $0.27 \mathrm{~g} / 100 \mathrm{~g}$ while nchanwu had the lowest $(0.07 \mathrm{~g} / 100 \mathrm{~g})$ as shown in Fig 2 . There was no significant difference between the steroid content of okazi, oha and nturukpa while the rest vegetables were significantly different from each other. Heating did not reduce the steroid content of the vegetables (Table 3), though some of the vegetables such as utazi and ahihara had a reduction in their steroid content after they were boiled. The resistance of steroid to the effect of heat is in line with the earlier report of Anderson (2002) that phytochemicals are not affected by processing including cooking. Agte, et al, 1999 reported that most of the phytochemicals which act as antioxidants are often affected by cooking. This agrees with what has been obtained in this work.

Oha had $0.28 \%$ content of flavonoid reflecting the highest when compared to the other raw GLV samples while ugu and olugbo had the lowest (Fig 3). Unlike steroid, flavonoid content of the GLV was significantly $(\mathrm{p}=0.05)$ reduced by the heat of cooking. It could be that boiling affected significantly the other components of flavonoid apart from anthocyanin. [Anthocyanin is a component of flavonoids]. Reasonable content of tannins was also found to be present in the fresh green vegetables with the values ranging from $0.13 \mathrm{~g} / 100 \mathrm{~g}$ to $0.28 \mathrm{~g} / 100 \mathrm{~g}$ (Fig 4) Tannin was presenting most of Olugbo leaf having a value of $0.22 \mathrm{~g} / 100 \mathrm{~g}$, while nchanwu had the lowest tannin content of $0.08 \mathrm{~g} / 100 \mathrm{~g}$. It has been said that the bitter pigment of onugbo leaf is contributed by its high content of tannin and resin (Okafor, 1983). This also certifies it's natural bitter taste in that tannin is a very bitter astringent compound found in plants. Tannin content of the vegetables was not affected by heating (Table 3) confirming report that phytochemicals including tannin, having antioxidant activities are not affected by cooking. There was no significant difference at $\mathrm{p}=0.05$ among the vegetables implying that the vegetable have similar range of tannin content.

Ahihara had the highest alkaloid content of $1.8 \mathrm{~g} / 100 \mathrm{~g}$ in the raw state while ugu had the lowest $(0.81 \mathrm{~g} / 100 \mathrm{~g})$. Olugbo had the highest alkaloid content of $0.84 \mathrm{~g} / 100 \mathrm{~g}$ in the boiled state. There was significant $(\mathrm{p}=0.05)$ difference in the alkaloid content of raw and boiled vegetables (Fig 5). Fresh vegetables were found to consistently have a higher content of alkaloid compared with boiled vegetables. The values reduced to the range of $0.30 \mathrm{~g} / 100 \mathrm{~g}$ to $0.84 \mathrm{~g} / 100 \mathrm{~g}$ as against 
$1.28 \mathrm{~g} / 100 \mathrm{~g}$ to $2.96 \mathrm{~g} / 100 \mathrm{~g}$ originally obtained from the vegetables in their fresh state. Ahihara which had the highest value in the fresh state lost so much of its alkaloid upon boiling. Oha leaf was found to contain the highest carotenoid content of $0.07 \mathrm{~g} / 100 \mathrm{~g}$ among the other vegetables (Fig. 6). The high level of carotenoid in oha could be because of its red/purple coloured leaf stock. Good enough oha is usually consumed with the leaf stock. The lowest content of carotenoid was found in ugu and okazi. They had $0.02 \mathrm{~g} / 100 \mathrm{~g}$ of carotenoid in both raw and cooked forms. Generally, cooking did not significantly $(\mathrm{p}=0.05)$ affect the carotenoid content of the vegetables. This indicates that carotenoid (coloured pigment) remained stable during cooking, though there was slight reduction in carotenoid content of oha and nturukpa following boiling.

\section{CONCLUSION}

The selected commonly consumed green leafy vegetables in southeast Nigeria contain substantial amount of phytochemicals, which are helpful in the prevention of some deadly diseases. Though these phytochemicals do not have a standard yet for a particular food as reported by (Liu, 2004). The phytochemicals were not affected by cooking except for flavonoids and alkaloids. This implies that the fear of losing these plant chemicals as a result of cooking need not arise. Vitamins and minerals can be lost (leached out) during cooking but not the phytochemicals. This is good news. This work also showed that the vegetables varied in their content of the phytochemicals except with respect to alkaloid and tannin where they had similar content statistically $(\mathrm{p}=0.05)$. Ugu one of the most cherished vegetables in southeast Nigeria is not very rich in most of these phytochemicals. Oha, ahihara and onugbo were rich in most the phytochemicals as was ascertained from this work. The GLV contained varying amount of the phytochemicals hence intake of mixture of these vegetables is recommended. This will enable derivation of full dose of the phytochemicals since no single plant is rich in all the plant chemicals.

\section{REFERENCES}

Agte, V.V., Tarwadi, K.V., and Chiplonkar, S.A., (1999). Phytate degradation during traditional cooking: significance of the phytic acid profile in cereal based vegetarian meals. J. Food. Anal. 12:161-167.

Agte, V.V., Tarwadi, K.V., Mengale, S. and Chiplonkar, S.A., (2000). Potential of indigenous green vegetables as natural sources of fortification of eight micronutrients. J. Food. Comp. Anal. 13:

885-891.

Akpanyung, E.O., Udoh, A.P and Akpan, E.J. (1995). Chemical composition of the edible leaves of Pterocarpus mildbreadii. Plant Foods Hum Nutr. 43 (3) :209.

Altar, M.V.A and Adeogun, O.A. (1995). Nutrient components of some tropical leafy vegetables. Food Chem. 53: 375-379.

Anderson, G.D., (2004). Phytocmemicals 2004. Dynamic Chiropractic.. 2 issue 01.Chung, K.T., Weichang, I. and Johnson, M.G., (1998). Are tannins a double edged sword in biology and health? Trends Food Science Technology. 4: 168175.

Davidson M.W., (2004). Phytochemical colletion. In: Molecular Expressions.File:///C:/ Documents 
Dewanto, V., Wu, X and Liu, R.H., (2002). Processed sweet corn has higher antioxidant activity. J. Agric. Food. Chem. 50:4959-4964.

Harborne, J.B (1973) Phytochemical Methods A guide to modern techniques of plant analysis. London. New York. Chapman and Hall.

Ihekoronye, A.I. and Ngoddy, P.O., (1985). Tropical fruits and vegetables. In: Integrated Food Science and Technology for the Tropics. Macmillan Education Ltd. p.293-275.

Kirk, H and Sawyer, R (1998) Frait Pearson Chemical Analysis of Food. 8th edition. Longman Scientific and Technical . Edinburgh. 211-212.

Liu, R.H., (2004). Potential synergy of phytochemicals in cancer prevention: mechanism of action. J. Nutrition. 134: 34795-34855.

Okafor, J.C., (1983). Horticulturally promising indigenous wild plant species of the Nigerian forest zone. Acta Horticulture. 123: 165-176.
Okeke, C.U., and Elekwa, I., (2003). Phytochemical study of the extract of Gongronema latifolium Benth. Journal of Health and Visual Sciences. 5 (1): 47-55.

Oliveri, C.S., (2003). Nutraceuticals, Phytochemicals, and Antioxidants- What are they about? OSU Extension fact sheet. HYG-505098.

Stahl, W., Junghhaus, A., and Sies, H., (1998). Carotenoid mixtures protect multi lamellar liposomes against oxidative damage synergistic effects of lycopene and lutein. FEBSLETT. 427 (2): 305-308.

Williamson, G., Dupont, M.S., Heaney,R.K., Roger, G., and Rhodes, M.J. (1997). Induction of slutathione $\mathrm{S}$ transferase activity in hepG2 cells by extracts of fruits and vegetables. Food Chem. 2: 157-160.

Table 3 Mean values of phytochemical contents in common green leafy vegetables

\section{Phytochemical (g/100g)}

Vegetable

\begin{tabular}{lcccccc} 
& Anthocyanin & Steroid & Flavonoid & Tannin & Alkaloid & Carotenoid \\
\hline Utazi & $0.07 \pm 0.01^{\mathrm{bc}}$ & $0.25 \pm 0.03^{\mathrm{a}}$ & $0.11 \pm 6.03^{\mathrm{c}}$ & $0.19 \pm 0.06^{\mathrm{a}}$ & $0.82 \pm 0.46^{\mathrm{a}}$ & $0.04 \pm 0.00^{\mathrm{b}}$ \\
Nturukpa & $0.04 \pm 0.00^{\mathrm{ed}}$ & $0.14 \pm 0.00^{\mathrm{e}}$ & $0.08 \pm 0.02^{\mathrm{dc}}$ & $0.19 \pm 0.04^{\mathrm{a}}$ & $0.88 \pm 0.46^{\mathrm{a}}$ & $0.05 \pm 0.01^{\mathrm{b}}$ \\
Nchanwu & $0.05 \pm 0.01^{\mathrm{cd}}$ & $0.07 \pm 0.01^{\mathrm{d}}$ & $0.07 \pm 0.03^{\mathrm{dc}}$ & $0.08 \pm 0.05^{\mathrm{a}}$ & $0.99 \pm 0.55^{\mathrm{a}}$ & $0.04 \pm 0.0^{\mathrm{b}}$ \\
Ugu & $0.02 \pm 0.00^{\mathrm{e}}$ & $0.25 \pm 0.01^{\mathrm{a}}$ & $0.03 \pm 0.01^{\mathrm{d}}$ & $0.13 \pm 0.05^{\mathrm{a}}$ & $0.81 \pm 0.47^{\mathrm{a}}$ & $0.02 \pm 0.00^{\mathrm{e}}$ \\
Olugbo & $0.02 \pm 0.00^{\mathrm{e}}$ & $0.27 \pm 0.01^{\mathrm{a}}$ & $0.04 \pm 0.00^{\mathrm{d}}$ & $0.22 \pm 0.07^{\mathrm{a}}$ & $1.81 \pm 0.34^{\mathrm{a}}$ & $0.04 \pm 0.00^{\mathrm{b}}$ \\
Oha & $0.1 \pm 0.02^{\mathrm{a}}$ & $0.13 \pm 0.01^{\mathrm{c}}$ & $0.22 \pm 0.06^{\mathrm{a}}$ & $0.18 \pm 0.05^{\mathrm{a}}$ & $1.19 \pm 0.89^{\mathrm{a}}$ & $0.7 \pm 0.01^{\mathrm{b}}$ \\
Ahihara & $0.08 \pm 0.02^{\mathrm{ba}}$ & $0.21 \pm 0.01^{\mathrm{b}}$ & $0.13 \pm 0.01^{\mathrm{bc}}$ & $0.13 \pm 0.03^{\mathrm{a}}$ & $1.68 \pm 1.28^{\mathrm{a}}$ & $0.05 \pm 0.01^{\mathrm{b}}$ \\
Okazi & $0.06 \pm 0.00^{\mathrm{bcd}}$ & $0.12 \pm 0.00^{\mathrm{c}}$ & $0.18 \pm 0.04^{\mathrm{ba}}$ & $0.11 \pm 0.02^{\mathrm{a}}$ & $1.28 \pm 0.84^{\mathrm{a}}$ & $0.02 \pm 0.00^{\mathrm{c}}$
\end{tabular}




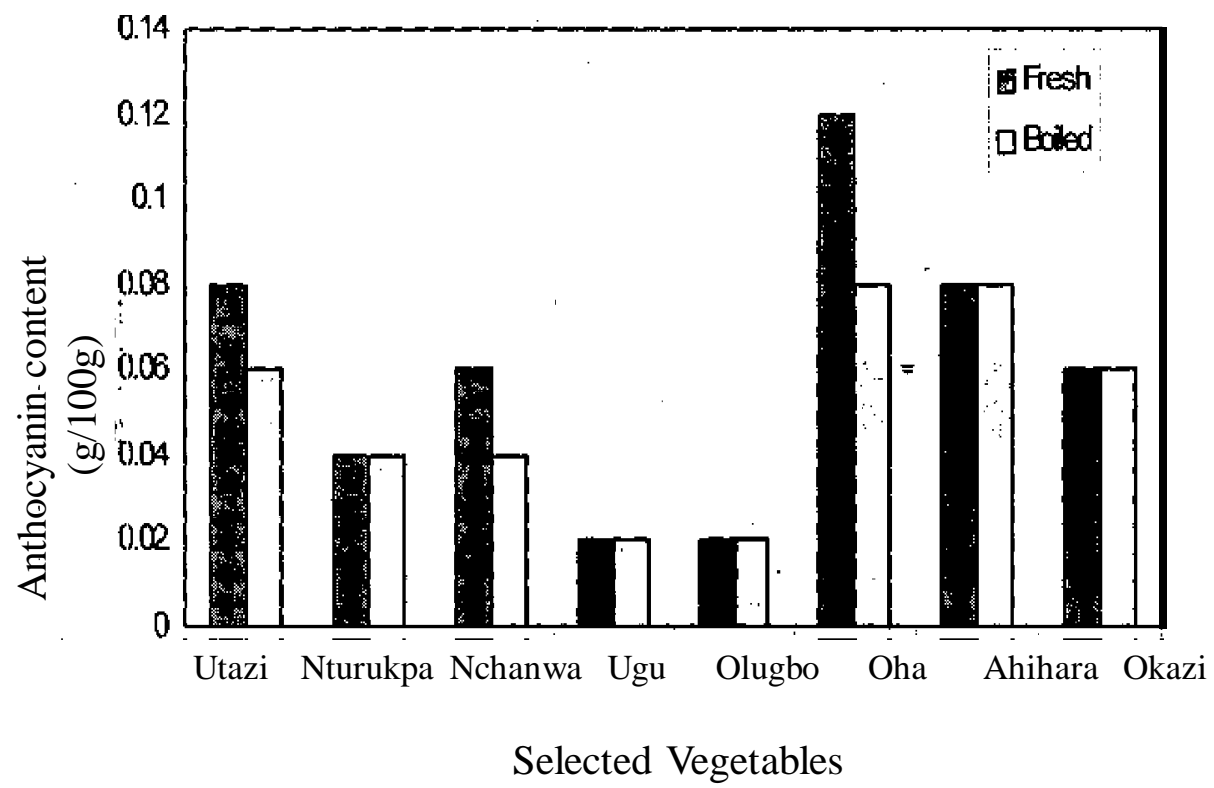

Fig 1. Anthocyarin content of fresh and boiled green vegetables

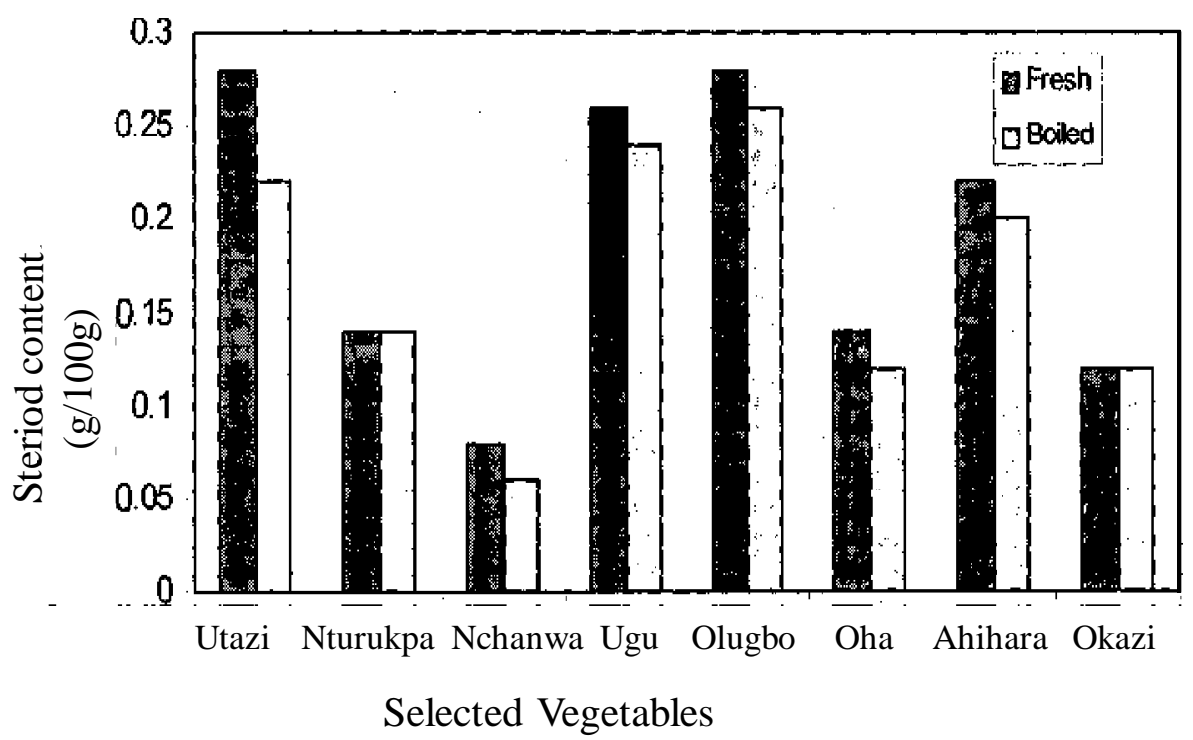

Fig 2. Steriod Content of fresh and boiled green vegetable 


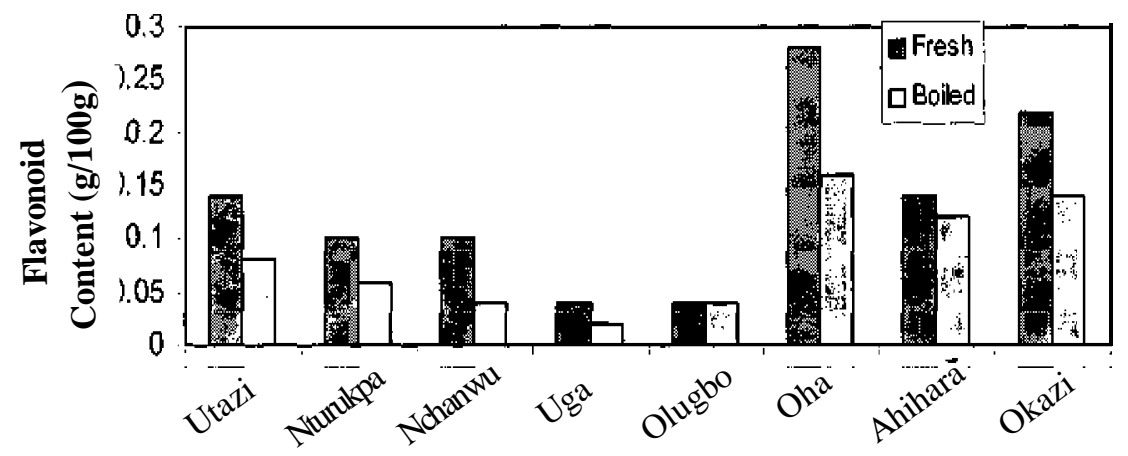

Selected Vegetables

Fig 3. Flavonid content (g/100) of freash and boiled green vegetables

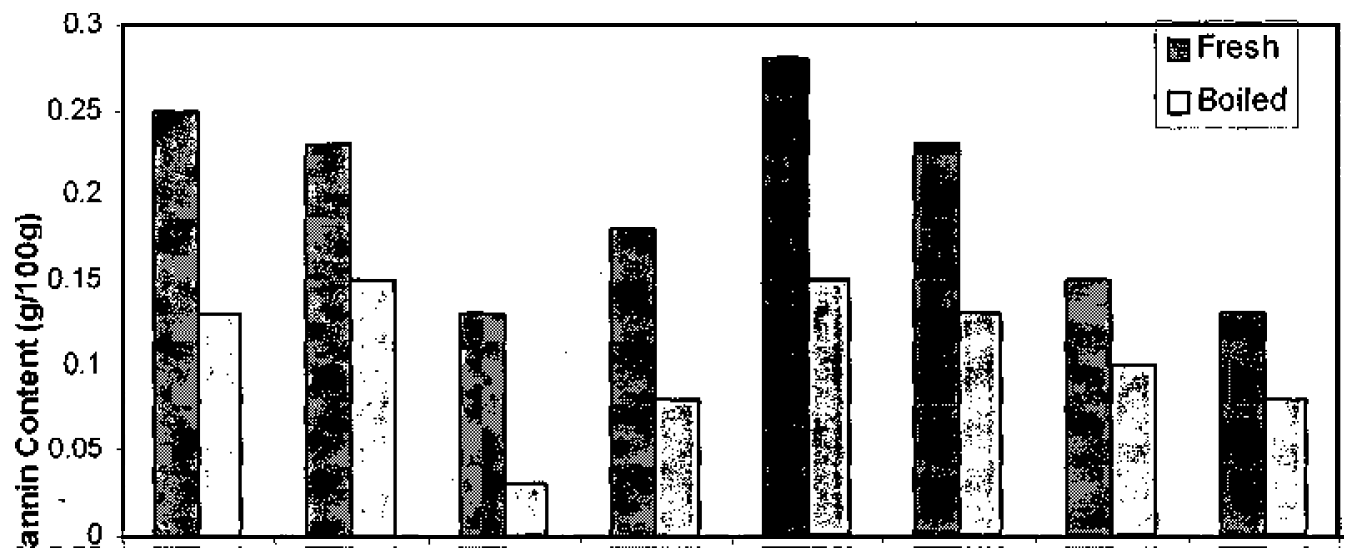

Selected Vegetables

Fig 4. Tannin content of freash and boiled green vegetables 


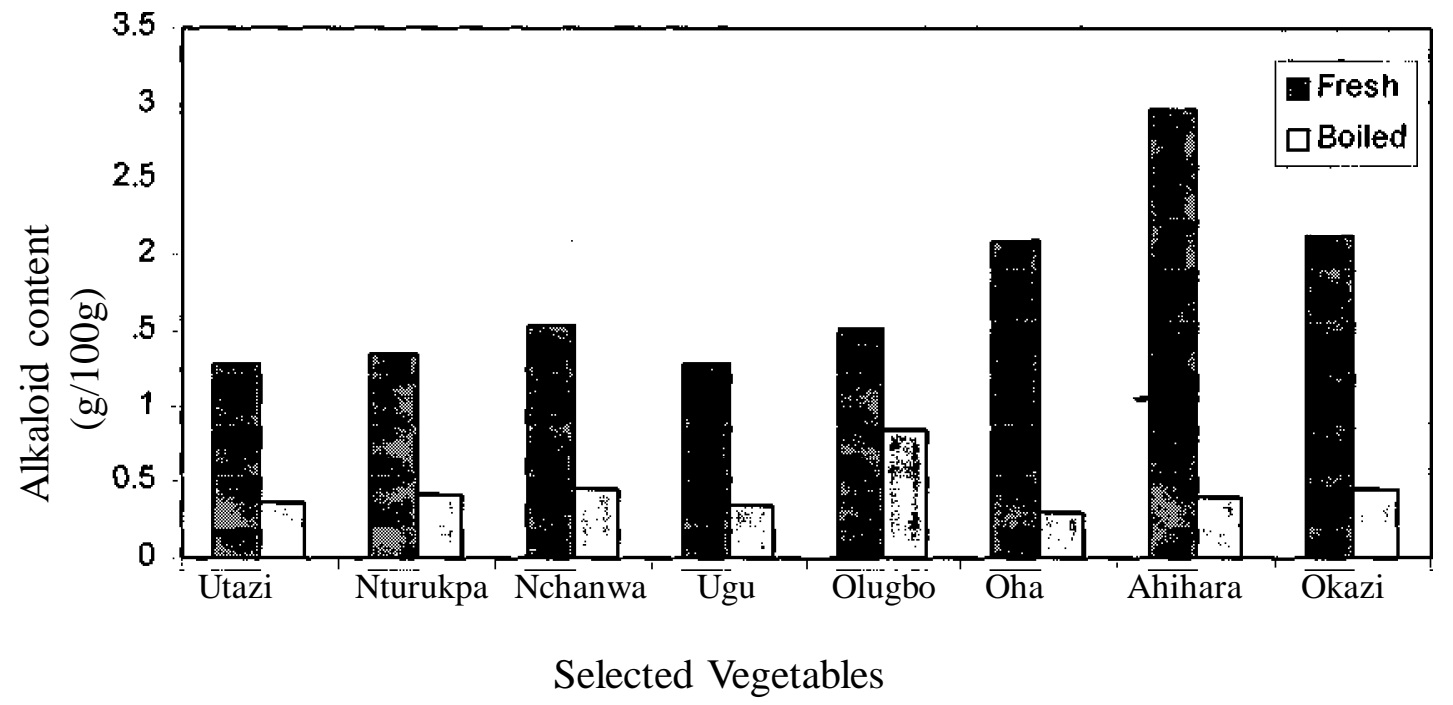

Fig 5. Alkaliod content of fresh and boiled green vegetables

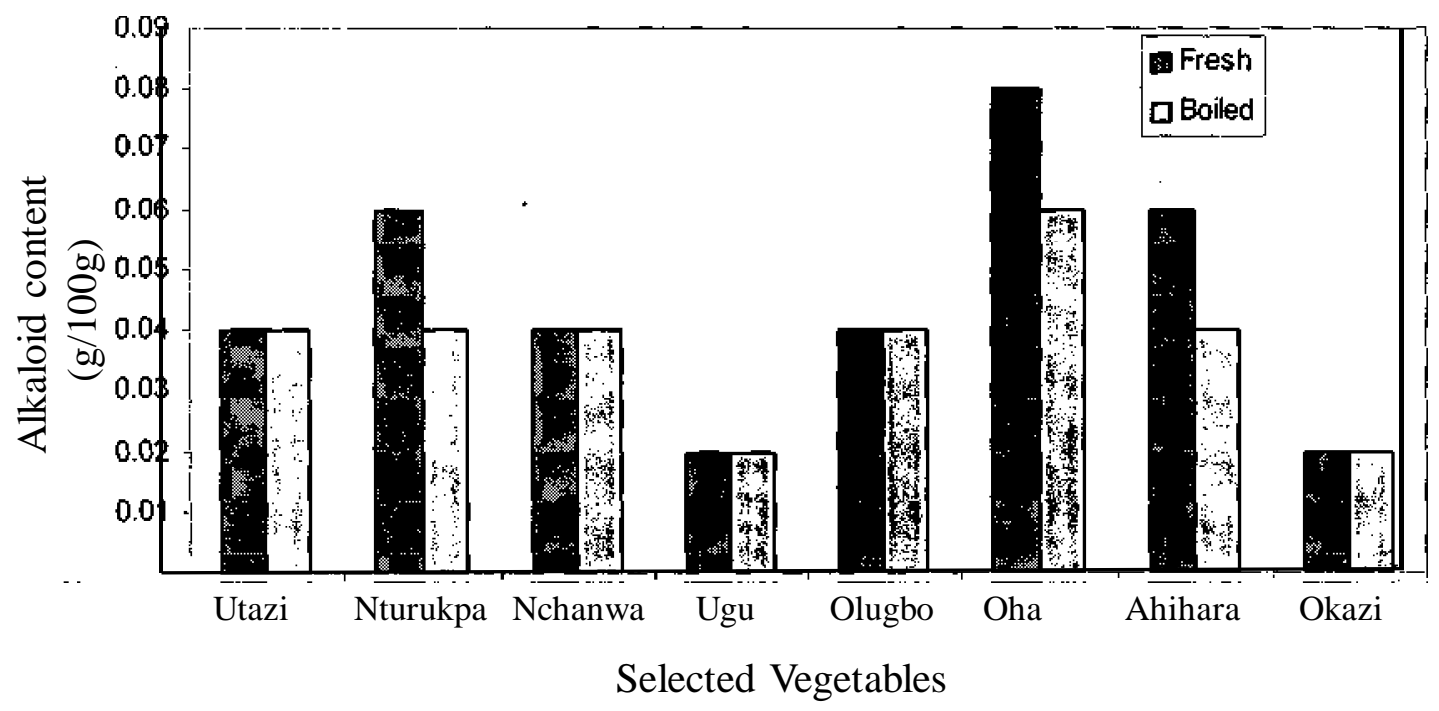

Fig 5. Alkaliod content of fresh and boiled green vegetables 